LA W RENCE LIVERMORE NATIONAL LABORATORY

C. Y. Wu, J. A. Becker, D. Cline August 18, 2006

Bambino: a segmented silicon detector system for TIGRESS 
This document was prepared as an account of work sponsored by an agency of the United States Government. Neither the United States Government nor the University of California nor any of their employees, makes any warranty, express or implied, or assumes any legal liability or responsibility for the accuracy, completeness, or usefulness of any information, apparatus, product, or process disclosed, or represents that its use would not infringe privately owned rights. Reference herein to any specific commercial product, process, or service by trade name, trademark, manufacturer, or otherwise, does not necessarily constitute or imply its endorsement, recommendation, or favoring by the United States Government or the University of California. The views and opinions of authors expressed herein do not necessarily state or reflect those of the United States Government or the University of California, and shall not be used for advertising or product endorsement purposes.

This work was performed under the auspices of the U.S. Department of Energy by University of California, Lawrence Livermore National Laboratory under Contract W-7405-Eng-48. 


\title{
Bambino: a segmented silicon detector system for TIGRESS
}

\author{
C.Y. Wu and J.A. Becker \\ Lawrence Livermore National Laboratory, Livermore, CA 94550 \\ D. Cline \\ Department of Physics, University of Rochester, Rochester, NY 14627
}

\begin{abstract}
Bambino is a charge-particle detector system with sufficient energy and position resolutions for the differentiation between projectile-like and target-like particles and for the needed Doppler-shift corrections to the detected $\gamma$ rays in TIGRESS. It consists of two annular silicon detectors having an active inner diameter of $22 \mathrm{~mm}$ and outer diameter of $70 \mathrm{~mm}$ and a thickness about $150 \mu \mathrm{m}$. They are placed $3.0 \mathrm{~cm}$ from the target and provide solid-angle coverage of $1.15 \pi \mathrm{sr}$. Each has 24 sectors in $\theta$ for the angle coverage between $20.1^{\circ}$ and $49.4^{\circ}$ and between $130.6^{\circ}$ to $159.9^{\circ}$ and has 16 sectors in $\phi$ for $2 \pi$ coverage. Three of those detectors and the matching preamplifiers, cables etc were ordered and received in 2005 at a cost about $\$ 50 \mathrm{k}$ funded by DOE/OS. The system was undergoing various tests at both LLNL and TRIUMF in the second quarter of 2006 and was successfully integrated into TIGRESS for the commission run in July/August 2006.
\end{abstract}

A side-accessible spherical target chamber, used in the commission run, was designed and built in Rochester in the second quarter of 2006 to accommodate this detector system at a cost about $\$ 28 \mathrm{k}$ funded by NSF and AFOSR.

This work was performed under the auspices of the U.S. Department of Energy by the University of California, Lawrence Livermore National Laboratory under contracts no. W-7405-ENG-48. The work performed at University of Rochester was supported by NSF and AFOSR.

This document was prepared as an account of work sponsored by an agency of the United States Government. Neither the United States Government nor the University of California nor any of their employees, makes any warranty, express or implied, or assumes any legal liability or responsibility for the accuracy, completeness, or usefulness of any information, apparatus, product, or process disclosed, or represents that its use would not infringe privately owned rights. Reference herein to any specific commercial product, process, or service by trade name, trademark, manufacturer, or otherwise, does not necessarily constitute or imply its endorsement, recommendation, or favoring by the United States Government or the University of California. The views and opinions of authors expressed herein do not necessarily state or reflect those of the United States Government or the University of California, and shall not be used for advertising or product endorsement purposes. 